\title{
Where Men Appear More Religious Than Women: Turning a Gender Lens on Religion in Israel
}

\author{
Landon Schnabel ${ }^{1}$ \\ Indiana University-Bloomington \\ Conrad Hackett \\ David McClendon \\ Pew Research Center
}

\begin{abstract}
Past research, typically focused on Christians in Christian nations, has found that women tend to be more religious than men. This study uses original nationally-representative data $(\mathrm{N}=5,601)$ with strategic oversamples of minority groups to examine variation in how religion and gender intersect across ethnoreligious identities in Israel. We demonstrate that Israel diverges from the typical pattern of women appearing more religious than men. In fact, Israeli men are consistently more religious than Israeli women on commonly used measures and frequently more religious on a broader set of questions specific to Judaism and Israel. Subgroup analyses highlight the intersectional nature of gender and religion, showing that men's greater religiosity in Israel is limited to Jews, and, more specifically, non-secular Jews. We suggest that gender gaps arise, at least in part, because religions are gendered institutions with gendered norms, expectations, and incentives, and that these norms, expectations, and incentives vary from religion to religion.
\end{abstract}

Last Revised: 2017-10-07

Keywords: Gender; Religion; Intersectionality; Israel; Ethnoreligious Identity; Jews; Muslims; Christians; Druze

Running Head: Gender Lens on Religion in Israel

Word Count: 7,295

Figures: 1

Tables: 3

\section{FORTHCOMING IN THE JOURNAL FOR THE SCIENTIFIC STUDY OF RELIGION}

\footnotetext{
${ }^{1}$ We are grateful to Orit Avishai, Benjamin Beit-Hallahmi, Steven Cohen, Alan Cooperman, Sergio DellaPergola, Sylvia Fishman, Ariela Keysar, Pamela Nadell, Brian Powell, Neha Sahgal, Alex Weinreb, and the anonymous reviewers for their helpful comments. All errors and omissions remain our own. Correspondence should be addressed to Landon Schnabel, Department of Sociology, Indiana University, 744 Ballantine Hall, 1020 E. Kirkwood Ave., Bloomington, IN, 47403 USA. Email: lpschnab@indiana.edu.
} 
Women tend to be more religious than men in the U.S. and in many places around the world (Baker and Whitehead 2016; Collett and Lizardo 2009; Freese and Montgomery 2007; Roth and Kroll 2007; Schnabel 2016; Sullins 2006). For example, they tend to say religion is more important in their lives, pray more often, and attend religious services more frequently. This gender gap in religion is so widespread that some religion scholars have argued it is a universal social fact and suggested that women may be biologically predisposed to be more religious (BeitHallahmi 2014; Miller and Stark 2002; Stark 2002). Even scholars who question the biological argument suggest that the gender gap in religion has more empirical support than other commonly accepted “social facts” (Hoffmann 2009). But recent research has begun to suggest religion is a part of our intersectional selves that it is experienced differently by people in different groups (Edgell 2017; Frost and Edgell 2017; Schnabel 2016; Wilde and Glassman 2016). Therefore, rather than women being universally more religious than men, this common pattern may be the result of particular social processes present among some groups but not others.

The apparent consistency of gender gaps in religion could be due to an overemphasis on Christians in past research (Smilde and May 2015; Smith et al. 2013). Schnabel (2015a) found that the gender gap is more pronounced among Christians than among other religious groups in the United States, and Hackett, Murphy, and McClendon (2016) demonstrated that the pattern of women being more religious than men is most consistently found in Christian-majority countries (also see Schnabel 2015b). By contrast, in Muslim-majority countries there are fewer gender differences in religious salience, and Muslim men often attend religious services more regularly than Muslim women in keeping with Islamic norms (Hackett et al. 2016). But gender gaps on affective measures of religion, such as religious salience and prayer frequency, are more 
consistent. Even Sullins (2006), who provided one of the most important critiques of simplistic biological arguments, suggested that gender differences on affective religiousness are universal.

Here we consider the understudied case of gender and religion in Israel. A few studies have examined gender differences among Jews in the United States and indicated that gender gaps for Jews may be different from those for Christians on commonly used measures (Hartman 2016; Hartman and Hartman 2009; Roth and Kroll 2007; Schnabel 2015a). Despite some research on gender gaps among Jews in the U.S., and despite Israel being unique from a global perspective as the world's only Jewish-majority country, the gender differences in religiosity phenomenon remains largely unexamined in Israel (but see DellaPergola 2001). ${ }^{2}$ In what we believe is the first nationally-representative study of gender differences in religious commitment and practice among ethnoreligious subgroups in Israel, we find that men appear more religious than women. Turning a gender lens on religion and gender as intersecting social structures, however, we demonstrate that this pattern is limited to Jews and, more specifically, to nonsecular Jews.

\section{Gendered Religions}

Several religion scholars have suggested that women are almost universally more religious than men (Beit-Hallahmi 2014; Stark 2002). Some of these scholars rely on essentialist arguments, such as the idea that men are biologically prone to greater risk, like violent crime and not attending religious services. ${ }^{3}$ If there is any variation in the supposed "social fact" that women are more religious than men, these scholars argue, the variation will arise only in non-

\footnotetext{
${ }^{2}$ Religion gender gaps in Israel were not DellaPergola’s (2001) focus, but the paper did include some findings that indicate Israeli men spend much more time on religious activities than do Israeli women.

${ }^{3}$ This particular theory relies on Pascal's Wager-a $17^{\text {th }}$ century apologetic argument - to assert that being irreligious is risky (Miller and Hoffmann 1995; Miller and Stark 2002; Stark 2002).
} 
Abrahamic ${ }^{4}$ religions that believe in more than one correct spiritual path where, these scholars argue, it is not so risky to be less religious (Miller 2000; Miller and Stark 2002). Even those who disagree with the biological argument still tend to argue that gender differences are a potentially universal social fact (Hoffmann 2009; Sullins 2006). Gender theory, however, suggests that gender is more than just an essential or universal characteristic. Instead, it is a dynamic, intersectional, and context-specific structure, status, and performance (Avishai and Irby 2017; Cornwall 2009; Risman 2004; Schnabel 2016) that is in the background (and sometimes foreground) of all social interaction (Ridgeway 2011; Ridgeway and Correll 2004). Breaking starkly from previous essentialist and universal explanations for gender differences in religiosity, we argue that religion is a key aspect of our intersectional selves as gendered people (Avishai, Jafar, and Rinaldo 2015; Edgell 2017; Schnabel 2016), that different religions are gendered in different ways (Hackett et al. 2016; Schnabel 2015a), and, subsequently, that people in different religions with varying gendered expectations should exhibit divergent gender gaps.

\section{Religions as Differently Gendered Institutions}

Social scientific research on religion has typically focused on Christians in Western Christian countries (Smilde and May 2015; Smith et al. 2013). Therefore, the limited attempts made to consider non-Christians in the literature on gender differences in religion deserve commendation. Nevertheless, most of the studies that made arguments for universal gender gaps relied primarily on datasets that provided a large amount of data on Christians in Christian-majority countries. In fact, when these studies did find variation in the pattern in the few available non-Christian countries they tended to discount them as "statistical artifacts" (Miller 2000:15) or “deviant

\footnotetext{
${ }^{4}$ The best-known Abrahamic religions are Christianity, Islam, and Judaism, but there are other lesser-known groups, such as Druze, Rastafarians, Samaritans, and others who also trace themselves to the same traditional figure.
} 
cases” (Miller and Stark 2002:1417). Even a study that did note variation across religious groups on certain public expressions of religion, including attendance, still argued that "gender differences are observed to be larger and near universal” on measures of affective religiousness, including religious salience and prayer frequency (Sullins 2006:851). We propose that religion is a gendered institution, that different religions are gendered in different ways, and that we should thus expect gender differences to vary from one setting to another.

To say religion is a gendered institution is an innovation in the gender differences in religion literature, but gender research on institutions besides religion—such as family, work, and politics - has long demonstrated that social institutions are gendered, that how they are gendered varies over time and space, and that different versions of the same type of institution can be gendered in different ways. For example, politics as an institution is clearly gendered, women are typically more liberal than men, and the two major political parties in the United States are gender-typed as feminine (Democrats) and masculine (Republicans) (Winter 2010). Subsequently, feminine-typed psychological traits-as measured by the Bem Sex Role Inventory — are closely linked to liberal politics among both women and men, and femininity can explain the gender gap in politics in at least the United States (McDermott 2016). Christianity, like Democratic politics, is feminine-typed and other religions may be gendered in different ways (Schnabel 2017a). Moreover, feminine-typed psychological characteristics—as measured by the Bem Sex Role Inventory_are linked to more positive views of Christianity and to more religiosity and, therefore, can help explain gender gaps in Christian contexts (Francis and Wilcox 1996, 1998; Thompson 1991; Thompson and Remmes 2002).

Qualitative research not focused on gender gaps in religiosity has consistently demonstrated that religions are gendered institutions, and that different religions have different 
gender norms and expectations for distinct ways of accomplishing the same purpose: promoting gendered religious values, expressing gendered religious identities, and, ultimately, differentiating between women and men in context-specific ways (Avishai 2008; Irby 2014; McDowell 2017; Rao 2015; Whitehead 2013). For example, Bartkowski and Read (2003) demonstrated that evangelicalism and Islam both differentiate between women and men and promote "proper” roles for women, but in different ways. For example, traditional gender values are expressed, and Muslim identity confirmed, with veiling in Islam but not evangelicalism, where other practices and symbols are used to similarly express gendered power and submission and confirm evangelical identity (Bartkowski and Read 2003; Read and Bartkowski 2000). Therefore, both religions are gendered, but in different ways.

The sociology of gender has consistently shown that many gaps historically thought to be rooted in essential differences between male and female bodies are the result of gender rather than sex differences, and, therefore, that these gaps vary and can even reverse in some contexts based on cultural norms and social experiences. Similarly, some research on gender and religion has begun to suggest that gaps are not universal, with studies finding smaller gaps among high earners (Hastings and Lindsay 2013; Schnabel 2016), liberals (Baker and Whitehead 2016), and those raised in less patriarchal households (Collett and Lizardo 2009). Some research has even suggested that the size of gender gaps will vary by religious group, with the largest and most consistent gaps among Christians (Hackett et al. 2016; Schnabel 2015a). Although these studies have found smaller gaps among some groups, they have still consistently found women to be more religious than men overall. However, we might expect these patterns to vary in a different religious context where, rather than women being expected to be more religious than men, on many religious behaviors men are expected to be more religious than women. 


\section{Gender and Jewish Religion}

Religions as social institutions are gendered in different ways, and Jewish religious norms are distinct from those for Christianity. For example, Judaism privileges religious practices over religious beliefs and feelings, and these practices are gendered (Fishman and Parmer 2008; Sullins 2006). As a concrete illustration of gendered Jewish norms and expectations, a minyana quorum of ten Jewish adults - is required for certain religious obligations such as public worship and prayer, and traditionally only men count toward this requirement. Similarly, Orthodox women are not permitted to lead prayers in worship services, and they are usually seated in a separate area of the synagogue where they cannot be seen by men, such as a balcony or behind a screen. Because a sexual quality is attributed to the female voice ("Kol Isha Erva”), in many Orthodox synagogues women are expected to refrain from singing out loud.

Although a relatively small proportion of the population, the Orthodox define Jewish religion in Israel and their gendered norms and expectations color the religious experiences of all observant Jews. In fact, their governance over key gendered experiences and institutions such as marriage influences even the lives of secular Jews, who often define themselves against the Orthodox and religious law. Orthodox Jewish men are obligated under traditional Jewish law ("halakha”) to follow a series of time-bound commandments ("mitzvot”), such as praying three times a day. Orthodox women do not have the same time-bound obligations, though they do have other obligations, such as responsibility for keeping family purity laws. Just as religious practices are gendered, so are religious experiences such as attending yeshiva-an experience encouraged for and traditionally only open to men that can promote religiosity. Clearly, Judaism, like other religions, is gendered, and we might expect different patterns among Jews than those among other religious groups. 
Although less frequently studied in the literature on gender and religion than Christians, when (American) Jews have been studied different patterns have sometimes emerged. For example, Schnabel (2015a) and Hartman (2016) found that gender gaps are smaller and less consistent among American Jews than among American Christians. Excellent qualitative work has been done on gender and religion in Israel, including scholarship that has taken an incisive gender perspective (Avishai 2008; Zion-Waldoks 2015), but quantitative research on gender gaps in Israel, especially among ethnoreligious subgroups, has been much less common. As far as we can determine, this is the first nationally-representative study of gender differences in religious commitment among subpopulations in Israel. We do not expect to find the same gender gaps among Israeli Jews that have been consistently among Christians around the world. In fact, rather than women seeming consistently and substantially more religious than men, the opposite pattern may emerge among Israeli Jews who face different gender norms, gendered social expectations, and even gender-specific religious obligations in a differently-gendered religious institution.

Just as we should consider potential variation in how gender and religion intersect differently by major religious groups such as Jews, Muslims, and Christians, we should also explore possible variation by subgroup identities. Nearly all Israeli Jews in the survey for this study identified with one of four identity categories: Haredi (commonly translated as “ultraOrthodox”), Dati (“religious”), Masorti (“traditional”), or Hiloni (“secular”). Despite living in the same small country and sharing many traditions, religious and secular Jews inhabit separate social worlds and are divided on many social and policy issues (Sahgal and Cooperman 2016). In fact, these four groups are so socially distinct that Jews tend to marry and develop most of their close friendships within their subgroup. 
Haredi is often translated as "ultra-Orthodox," but has a more literal meaning of "fearing God.” Haredim make up about 9\% of Israeli Jews, are sectarian and highly observant of Jewish religious law (halakha), and would prefer religious law to take precedent over democratic principles. Dati can be translated as "religious” or “modern Orthodox.” Datiim make up about 13\% of Israeli Jews, are more integrated into Israeli society than Haredim, and are generally observant of practices like eating kosher and keeping the Sabbath. Masorti Jews are a liminal group that occupies a middle ground between Orthodoxy and secularism. Whereas observance is expected among the two Orthodox groups, observance among Masortim is more of an option than a requirement. Masortim make up about 29\% of Israeli Jews, report varying levels of beliefs and practices, and are the most religiously diverse of these four self-identified types of Jews. Hiloni Jews are secular, but many observe some religious traditions and holidays. Almost half of Israeli Jews identify as Hilonim (49\%), and Hilonim prefer secular democratic governance and generally oppose the Orthodox rabbinate's control over marriage and divorce (for more on these four categories and how they differ from one another, see Sahgal and Cooperman 2016). Because religious Jewish women and men face gendered religious norms and expectations that secular Jews do not face, we anticipate that there will be fewer gender differences among secularidentifying Jews than among religious-identifying Jews, as well as possible variation in the size of gender gaps by different categories of religious-identifying Jews.

Turning a gender lens on religion in both theory and empirical approach, we consider whether gender gaps in Israel vary in comparison to past research on other contexts, whether these patterns vary by major religious groups, and furthermore whether these patterns vary by Jewish subgroup. We expect—based on gender theory, gendered Jewish norms and expectations, and limited previous research—-that gender gaps will vary by religious group in Israel. 


\section{Methods}

We use original data from the nationally-representative 2014 Pew Israel Survey which are uniquely suited to examine gender gaps in religion across ethnoreligious subpopulations in Israel. For this survey, 5,601 face-to-face interviews with Israeli adults were conducted between October 14, 2014 and May 21, 2015. To determine whether patterns vary among different groups of people in Israel, five groups were oversampled as part of the probability-based survey design: Jews living in the West Bank, Haredim (the “ultra-Orthodox”), Christian Arabs, Arabs living in East Jerusalem, and Druze. The sample includes 3,789 Jews, 871 Muslims, 468 Christians, and 439 Druze. An additional 34 respondents belonged to other religions or were religiously unaffiliated. The overall response rate was 57\% (Sahgal and Cooperman 2016).

Following past research on gender differences in religion we focus on gender gaps in measures of attendance frequency (weekly=1), prayer frequency (daily=1), and religious salience (very important $=1$ ), ${ }^{5}$ but also consider 25 additional measures relevant to Israeli Jews. Our focus on practice and commitment parallels past research, allows for comparison across groups, and takes into account the fact that Judaism emphasizes practice over belief. ${ }^{6}$ The attendance question asks about attendance frequency outside of special occasions such as weddings and funerals. The prayer question measures prayer frequency outside of religious services and does not ask separately about different prayer forms (e.g., tefillah, brachot, and tehilim) so as to be comparable across major religious groups. ${ }^{7}$ The religious salience question asks how important

\footnotetext{
${ }^{5}$ These levels were selected for theoretical salience, to follow past research, and ease of interpretation. The patterns hold across alternative coding specifications and in ALSOS regression.

${ }^{6}$ Religious practice and commitment are typically better and more broadly applicable measures of religiousness than are beliefs. Beliefs tend to apply differently across groups and to better describe the type rather than the level of a person's religiosity. For example, just because an evangelical is a biblical literalist does not mean they are more religious than a more committed and frequently practicing Catholic for whom belief in literalism is less relevant. ${ }^{7}$ Men and women likely differ in their propensity to offer distinct types of prayer due to Jewish norms. For example, women may be more likely to read tehilim (psalms), but we are not able to examine such variation. Our more
} 
religion is to the respondent's life. The online appendix includes question wording for each of our key religiosity items.

We report weighted levels of religiousness for women and men first among all Israelis, taking design effects into account when calculating significance. In order to consider important variation across groups in keeping with intersectionality theory, we then consider gender differences separately by religious category (i.e., Jewish, Muslim, Christian, and Druze), and finally by Jewish subcategory (Haredi, Dati, Masorti, and Hiloni). ${ }^{8}$ Although we focus on presenting clear, simple, and easily interpretable results, we also present more complex ancillary analyses that confirm the main findings. These ancillary analyses use alternating least squares optimized scaling (ALSOS) multivariate regression ${ }^{9}$ on the religion measures in multiple categories. ${ }^{10}$ For the small amount of missing data on categorical covariates we include missing as an additional category, and for the small amount of missing data on continuous covariates (about .1\% of the sample) we employed imputation. As with the other analyses, survey weights are used in the regression analyses.

general measure should capture respondents' sense of their overall prayer frequency outside of worship services in a way that can be compared with other religious groups (i.e., Muslims, Christians, and Druze).

${ }^{8}$ These weights are based, in part, on information from the Central Bureau of Statistics of Israel and account for the oversamples mentioned above. The sample is comparable to data from the Israel Social Survey.

${ }^{9}$ ALSOS is a method for estimating models without making arbitrary and ultimately unjustifiable assumptions about category spacing for ordinal outcomes (DeLeeuw, Young, and Takane 1976; Jacoby 2014). ALSOS provides bestfitting estimates of value points and individual vectors and thus transforms categorical data into linear data (Jacoby 2014). In other words, ALSOS procedures are used to rescale ordinal dependent variables with empirically meaningful spacing between categories. Coefficients for this method can be interpreted similarly to how OLS estimates would be interpreted because ALSOS transformation retains the original means and standard deviations of the untransformed variables. The optimal scaling procedure was conducted using Armstrong's ALSOS R package.

${ }^{10}$ As shown in the online appendix, the six attendance categories ranged from never to more than once a week, seven prayer categories from never to several times a day, and four salience categories from religion being not at all important to very important. 


\section{Results}

\section{Gender Gaps by Major Religious Group}

Israel consistently breaks from the pattern of women being more religious than men. In fact, Table 1 shows that Israeli men appear more religious than Israeli women across standard religiosity measures. In Israel, men are more likely than women to say they attend religious services weekly (40\% vs. 21\%), that they pray daily (30\% vs. 24\%), and that religion is very important in their lives (39\% vs. 33\%). This pattern of men appearing significantly more religious than women in Israel goes against the conventional wisdom in the literature. Therefore, we cross-checked the patterns in supplemental analyses using International Social Survey Programme data — from the 2008 religion module — and found the same "reverse” gender gap in religiosity in Israel. ${ }^{11}$

\section{[Table 1 about here]}

Why does Israel have a unique gender gap in religiosity? Israel’s most obvious distinctive feature is that it is the world's only majority-Jewish country. This explanation for the divergent gender gap in religion is affirmed when we consider how gender differences vary by religious group. Table 1 shows that men’s consistent religious advantage in Israel is present only among Jews, who face specific religious gender expectations. Jewish men are more likely than Jewish women to report attending religious services weekly (37\% to 18\%) and praying at least daily (26\% to $16 \%$ ), in keeping with Jewish norms. There is a smaller, but still notable, gap on affective religious salience: $35 \%$ of Jewish men and only $25 \%$ of Jewish women say that religion is very important in their lives. By these standard survey measures, Jewish men appear more religious than Jewish women in Israel. The reverse is true, however, for Christians, Druze and, 
on measures other than attendance, Muslims. Among these smaller minority groups, the tendency is for women to be more religious than men, which matches what has been found in past research on many countries besides Israel. ${ }^{12}$

We elected to present the results in a straightforward manner for the sake of clarity and ease of substantive interpretation because (1) the patterns are not sensitive to our dichotomization of the religiosity measures and (2) sociodemographic factors do not drive the pattern of Jewish men being more religious than Jewish women. To demonstrate the robustness of the patterns we present an example of confirmatory ancillary analyses in Table 2. As shown in this table, ALSOS regression with interactions between gender and major religious group provides results equivalent to what we presented in Table 1, and gender gaps in models with sociodemographic controls are generally similar to models without them.

[Table 2 about here]

Gender Gaps by Jewish Subgroup

The patterns clearly vary by major religious group (i.e., Jews, Muslims, Christians, and Druze), but do the distinctive gender patterns vary across Jewish subgroups? As we noted above, nearly all Israeli Jews in this survey identified with one of four categories: Haredi (commonly translated as “ultra-Orthodox”), Dati (“religious”), Masorti (“traditional”), or Hiloni (“secular”). Despite living in the same small country and sharing many traditions, religious and secular Jews inhabit

\footnotetext{
${ }^{11}$ The ISSP data and other data on Israel do not include the same oversamples of non-Jewish religious groups that enable us to present the subsample analyses we show here.

${ }^{12}$ When measuring something like religious commitment, it is important to remember it could be socially desirable, and socially desirable in gendered ways. If there are gendered norms about religious commitment, respondents may lean toward reporting more of the type of religious commitment they perceive is expected of their gender. In comparisons of survey reports and time diaries, Brenner (2014) found that women were more likely than men to overreport prayer frequency in Turkey and the Palestinian territories. Although we do not have evidence of overreporting by gender in Israel, any potential desirability bias could be interpreted as the result of internalized
} 
separate social worlds, are divided on many social and policy issues, and face different gendered expectations and experiences.

Figure 1 shows that Hiloni Jews are distinct from other Jews in that Hiloni men are no more religious than Hiloni women because both are at or near $0 \%$ on weekly attendance, daily prayer, and high religious salience. Among each of the other Jewish subgroups there are significant differences, with the largest and most consistent gender gap on attendance. This difference, like the similar pattern in Islam for men to attend services more frequently, suggests that Jewish men seem to be more religious than Jewish women because of norms about men’s proper religious roles. In addition to attendance, both of the more moderate religious groups, Datiim and Masortim, have significant gender gaps on daily prayer. Only among the liminal group-Masortim, who describe themselves as neither strictly religious nor wholly secular-are men significantly more likely than women to say that religion is very important in their lives.

[Figure 1 about here]

\section{Gender Gaps on Additional Measures Relevant to Jews}

Directly comparing levels of religious commitment by gender to determine whether men or women are "more religious” may seem jarring in a context where men and women are expected to be religious in different ways. ${ }^{13}$ The gendered expectations for expressing distinct forms of religious practice and commitment are so strong for Israeli Jews that some experts with whom we shared the above results were uncertain about whether greater attendance and prayer frequency really indicate that Jewish men are more religious than Jewish women. Therefore, we

gendered norms about desirable behavior, reflecting our overall argument that religions are gendered institutions with gendered norms that vary across religion and context.

${ }^{13}$ For example, a good number of men but very few women reported attending Jewish religious education in the form of yeshiva or kolel. Jewish education, therefore, is clearly a gendered expectation and experience specific to 
considered gender gaps on a number of additional measures relevant to Jews. Table 3 shows gender gaps among Jews in Israel on 25 additional items measuring belonging, behaving, and believing. ${ }^{14}$ On 16 items there were not significant gender differences, but on 9 items there was a significant gender gap. On each of these 9 items, men scored higher than women. ${ }^{15}$ In addition to examining the 25 additional measures among all Jews, we considered them for each of the Jewish subgroups. As with the differences in our primary measures, differences between women and men on these additional measures tended to be largest among Masortim.

[Table 3 about here]

Although this broader set of measures does not encompass all aspects of Jewish religious life and may over-emphasize public forms of religiosity that are more expected of men-women would likely score higher on some measures we did not have, such as frequency of personally lighting Sabbath candles-Israeli Jewish men appear more religious than women on many measures. ${ }^{16}$ It should not be surprising that men are more likely to study the text daily or for yeshiva or kolel to be their highest level of education because of gendered norms and expectations regarding these measures of religion. It is striking, however, that Jewish men were more likely than women to report that they do not ride in vehicles on the Sabbath and that they

Judaism. Additional analyses demonstrate that Jewish religious education mediates a substantial and significant proportion of Jewish gender gaps in religiosity.

${ }^{14}$ We focus on items such as salience and attendance frequency because they measure levels of religiousness, whereas beliefs tend to measure types of religiousness. In these additional analyses we include beliefs because some people see having more orthodox beliefs as indicating a greater level of religiousness.

${ }^{15}$ We also considered a set of combined measures that approximate being "highly observant” vs. "not highly observant." In this comparison the gender gap is even larger than on individual measures, with 31\% of Jewish men but only $14 \%$ of Jewish women being "highly observant."

${ }^{16}$ Future research should consider additional group-specific measures that are more gendered in the opposite direction, and are traditional mitzvot of women rather than men, to consider the ways women in Israel could appear just as if not more religious than men. 
fasted all day during last Yom Kippur — two important practices that are expected of both men and women. ${ }^{17}$

\section{Discussion}

A great deal of ink has been spilled trying to explain purportedly universal gender differences in religious commitment. But by the measures and standards of the gender differences in religiosity literature, men are more religious than women in Israel. This pattern contradicts the supposed “social fact” of women’s “universally” greater religiosity, and changes the conversation on gender and religion. Although our findings refute some past theories, they are consistent with the religion-as-gendered-institution framework we laid out, which would suggest Jewish men seem more religious for the same reasons Muslim men attend services more frequently and Christian women seem consistently more religious. Just as Muslim teachings prescribe attendance for men and Christian contexts link religiosity, femininity, and motherhood, Jewish men encounter religious cultural norms that encourage them to publicly express their religiosity in ways that could then foster greater religious commitment (Schnabel 2015b, 2016; Sullins 2006; Woodhead 2008). Put simply, observant Jewish men are expected to engage in regular ritual practice, religion is therefore a central part of their everyday existence, and they subsequently say religion is important in their lives. We might expect that secular Jews would not face the same gendered expectations, and, indeed, there is no gender gap among secular Jews.

Based on the results presented in this study, we suggest that gender gaps arise, at least in part, simply because religions are gendered institutions with gendered norms, experiences, and social and psychological incentives (Avishai 2016; Avishai et al. 2015; Edgell, Frost, and

\footnotetext{
${ }^{17}$ Although fasting is expected of both men and women, this expectation can still be gendered. In some occasions, rabbinic law is more flexible with women's fasting requirements, even on Yom Kippur, if they are feeling unwell
} 
Stewart 2017; Schnabel 2015b, 2016; Whitehead 2013), and that these norms, experiences, and incentives vary from one religious context to another. To put these gendered norms and expectations in more concrete terms, only men count toward a minyan, synagogues are often gender-segregated, and women are not permitted to participate in some Jewish practices. Whereas patriarchal forms of Christianity exclude women from leadership roles but encourage their public worship, patriarchal forms of Judaism contribute to a reverse gender gap by excluding women from the public religious sphere. And while one could say that Christian churches are a place for women, one could likewise say that Jewish synagogues are a place for men. Additionally, Orthodox Jewish men are obligated under traditional Jewish law to follow a series of time-bound commandments, such as regular daily prayer. Orthodox women do not have the same time-bound obligations, though they do have other obligations. Subsequently, gender gaps are largest on the more communal and public aspects of religiosity and typically smaller on the more internal or affective measure of religion's importance in a person's life.

Although Israeli Jewish men score higher on the standard religious practice and commitment measures we examined in this study, Israeli Jewish women would not necessarily score lower on all religion and spirituality-related measures and may in fact score higher on belief in certain supernatural phenomena. ${ }^{18}$ For example, we might expect that Jewish women would be more likely to personally light Sabbath candles and take primary responsibility for the Sabbath, holiday meals, and Taharat Ha-Mishpachah ("Laws of Family Purity”) because these practices are expected of them. Likewise, while women may generally outnumber men in

(Judaic law regards women as having less physical stamina than men) or have recently given birth and are nursing. ${ }^{18}$ Additional analyses of the 2008 ISSP religion module indicate that although men consistently score higher on many common measures, Jewish women in Israel tend to be more likely to believe in certain supernatural phenomena. This trend in supernatural beliefs is not limited to beliefs that are generally compatible with Jewish teachings — e.g., miracles, an afterlife, and a God concerned with human affairs—and instead extends and is actually 
Christian churches, Christian men would appear more religious if we were to only focus on masculine-typed practices such as serving in prominent congregational leadership roles (e.g., minister, elder, usher, board member, adult-class Sunday School teacher, etc.) and participating in certain gendered church volunteer activities (e.g, church building and grounds maintenance, audio-visual management, etc.).

The patterns clearly vary by major religious tradition, but they also vary by subgroup within the same tradition. Gender differences are largest among Masortim and we propose a couple possible explanations rooted in the fact that Masortim are a liminal (or in-between) group. First, ceiling and floor effects may mute gender gaps at the high and low ends of religiosity. ${ }^{19}$ Second, and relatedly, people may be more likely to indulge their gendered selves when faced with options instead of requirements. For example, occupational gender segregation is particularly high in more economically-developed contexts with self-expressive value systems that create opportunities and incentives for people to choose the occupation they want rather than feeling compelled to do whatever pays best (Charles and Bradley 2009). In other words, the presence of choice rather than compulsion creates more opportunity for people to indulge their “gendered selves" — and thus women are more likely to select feminine-typed occupations, such as social services, over higher-paying masculine-typed occupations. Likewise, among the group for whom religiousness is an acceptable but not compulsory option for self-expression we see a wider gender divide with men tending toward the "man-typed” option. In most Christian settings

more pronounced on other phenomena such as reincarnation, Nirvana, and supernatural powers of deceased ancestors.

${ }^{19}$ Men consistently appearing more religious than women even extended to identification with the four categories, with men being somewhat more likely to identify as Haredim and women as Datiim. Moreover, men were a bit more likely to identify as Masortim and women as Hilonim. 
the "man-typed" option is less religiosity, but among Jews in Israel it appears to be more religiosity.

A wide range of competing theories have been posited to explain the supposed social fact of women's greater religious commitment, but we have shown the opposite pattern is true in Israel where men are more religious than women. Although this finding would be perplexing in many previous frameworks, we expected variation by context and religious group. In our new framework of gendered religions and context-specific gender expectations, we anticipated that Jewish men in Israel would be more religious because the religion, and the society in which it is situated, expects it of them. This framework provides a straightforward explanation for gender differences among other religious groups as well. Among Christians, for example, women may be more religious than men simply because religious commitment and practice are femininetyped (Schnabel 2017a), Christian women face social expectations to be religious (Edgell et al. 2017), church seems like a place for women (Junge and Storkel 2014), and Christian women get more out of religion than men (Schnabel 2017b).

We hope future research will further analyze Israeli and American Jews, how gender gaps in religion vary by country and groups within countries, and how gendered expectations, sanctions, and incentives are implicated in gender gaps across religious groups. We anticipate gendered expectations — and gendered social and psychological incentives received from gendered religions—-will continue to explain why gender gaps in religiosity emerge. 


\section{REFERENCES}

Avishai, Orit. 2008. “'Doing Religion’ in a Secular World: Women in Conservative Religions and the Question of Agency.” Gender \& Society 22(4):409-33.

Avishai, Orit. 2016. “Gender.” Pp. 373-94 in Handbook of Religion and Society, edited by David Yamane. New York: Springer.

Avishai, Orit and Courtney Ann Irby. 2017. "Bifurcated Conversations in Sociological Studies of Religion and Gender.” Gender \& Society 31(5):647-76.

Avishai, Orit, Afshan Jafar, and Rachel Rinaldo. 2015. “A Gender Lens on Religion.” Gender \& Society 29(1):5-25.

Baker, Joseph O. and Andrew L. Whitehead. 2016. “Gendering (Non)Religion: Politics, Education, and Gender Gaps in Secularity in the United States.” Social Forces 94(4):162345.

Bartkowski, John P. and Jen’nan Ghazal Read. 2003. “Veiled Submission: Gender, Power, and Identity among Evangelical and Muslim Women in the United States.” Qualitative Sociology 26(1).

Beit-Hallahmi, Benjamin. 2014. Psychological Perspectives on Religion and Religiosity. Routledge.

Brenner, Philip S. 2014. “Testing the Veracity of Self-Reported Religious Practice in the Muslim World.” Social Forces 92(3):1009-37.

Charles, Maria and Karen Bradley. 2009. “Indulging Our Gendered Selves? Sex Segregation by Field of Study in 44 Countries.” American Journal of Sociology 114(4):924-76.

Collett, Jessica L. and Omar Lizardo. 2009. “A Power-Control Theory of Gender and Religiosity.” Journal for the Scientific Study of Religion 48(2):213-31. 
Cornwall, Marie. 2009. “Reifying Sex Difference Isn’t the Answer: Gendering Processes, Risk, and Religiosity.” Journal for the Scientific Study of Religion 48(2):252-55.

DeLeeuw, Jan, Forrest Young, and Yoshio Takane. 1976. “Additive Structures in Qualitative Data, an Alternating Least Squares Method with Optimal Scaling Features.” Psychometrika 41(4).

DellaPergola, Sergio. 2001. “Jewish Women in Transition: A Comparative Sociodemographic Perspective.” Studies in Contemporary Jewry 16(1):209-42.

Edgell, Penny. 2017. “An Agenda for Research on American Religion in Light of the 2016 Election.” Sociology of Religion 78(1):1-8.

Edgell, Penny, Jacqui Frost, and Evan Stewart. 2017. “From Existential to Social Understandings of Risk: Examining Gender Differences in Non-Religion.” Social Currents Online 1st.

Fishman, Sylvia Barack and Daniel Parmer. 2008. Matrilineal Ascent/Patrilineal Descent: The Gender Imbalance in American Jewish Life. Boston, MA: Hadassah-Brandeis Institute.

Francis, Leslie J. and Carolyn Wilcox. 1996. “Religion and Gender Orientation.” Personality and Individual Differences 20(I):119-21.

Francis, Leslie J. and Carolyn Wilcox. 1998. "Religiosity and Femininity: Do Women Really Hold a More Positive Attitude toward Christianity?” Journal for the Scientific Study of Religion 37(3):462-69.

Freese, Jeremy and James D. Montgomery. 2007. “The Devil Made Her Do It? Evaluating Risk Preference as an Explanation of Sex Differences in Religiousness.” Pp. 187-230 in Advances in Group Processes: The Social Psychology of Gender, edited by Shelley J. Correll. Oxford: Elsevier.

Frost, Jacqui and Penny Edgell. 2017. “Distinctiveness Reconsidered: Religiosity, Structural 
Location, and Understandings of Racial Inequality.” Journal for the Scientific Study of Religion In Press.

Hackett, Conrad, Caryle Murphy, and David McClendon. 2016. The Gender Gap in Religion around the World. Washington, D.C.: Pew Research Center.

Hartman, Harriet. 2016. “Gender Differences in American Jewish Identity: Testing the Power Control Theory Explanation.” Review of Religious Research Online 1st.

Hartman, Harriet and Moshe Hartman. 2009. Gender and American Jews: Patterns in Work, Education \& Family in Contemporary Life. Waltham, MA: Brandeis University Press.

Hastings, Orestes P. and D.Michael Lindsay. 2013. "Rethinking Religious Gender Differences: The Case of Elite Women.” Sociology of Religion 74(4):471-95.

Hoffmann, John. 2009. “Gender, Risk, and Religiousness: Can Power Control Provide the Theory?” Journal for the Scientific Study of Religion 48(2):232-40.

Irby, Courtney Ann. 2014. “Dating in Light of Christ: Young Evangelicals Negotiating Gender in the Context of Religious and Secular American Culture.” Sociology of Religion 75(2):260-83.

Jacoby, William G. 2014. "Is There a Culture War? Conflicting Value Structures in American Public Opinion.” American Political Science Review 108(4):1-18.

Junge, Daniel and Bryan Storkel. 2014. Fight Church. United States: LionsGate Entertainment. McDermott, Monika. 2016. Masculinity, Femininity, and American Political Behavior. New York: Oxford University Press.

McDowell, Amy D. 2017. “Aggressive and Loving Men.” Gender \& Society 31(2):223-44. Miller, Alan. 2000. "Going to Hell in Asia: The Relationship between Risk and Religion in a Cross Cultural Setting.” Review of Religious Research 42(1):5-18. 
Miller, Alan and John Hoffmann. 1995. "Risk and Religion: An Explanation of Gender Differences in Religiosity.” Journal for the Scientific Study of Religion 34(1):63-75.

Miller, Alan and Rodney Stark. 2002. “Gender and Religiousness: Can Socialization Explanations Be Saved?” American Journal of Sociology 107(6):1399-1423.

Rao, Aliya Hamid. 2015. “Gender and Cultivating the Moral Self in Islam: Muslim Converts in an American Mosque.” Sociology of Religion 76(4):413-35.

Read, Jen’nan Ghazal and John P. Bartkowski. 2000. “To Veil or Not to Veil? A Case Study of Identity Negotiation among Muslim Women in Austin, Texas.” Gender \& Society 14(3):395-417.

Ridgeway, Cecilia L. 2011. Framed by Gender: How Gender Inequality Persists in the Modern World. New York: Oxford University Press.

Ridgeway, Cecilia L. and Shelley J. Correll. 2004. "Unpacking the Gender System: A Theoretical Perspective on Gender Beliefs and Social Relations.” Gender \& Society 18(4):510-31.

Risman, Barbara J. 2004. “Gender as a Social Structure.” Gender \& Society 18(4):429-50.

Roth, Louise Marie and Jeffrey C. Kroll. 2007. "Risky Business: Assessing Risk Preference Explanations for Gender Differences in Religiosity.” American Sociological Review 72(2):205-20.

Sahgal, Neha and Alan Cooperman. 2016. Israel's Religiously Divided Society. Washington, D.C.: Pew Research Center.

Schnabel, Landon. 2015a. "How Religious Are American Women and Men? Gender Differences and Similarities.” Journal for the Scientific Study of Religion 54(3):616-22.

Schnabel, Landon. 2015b. More Religious, Less Dogmatic: Reexamining Gender Differences in 
Religion. Paper presented at the annual meetings of the American Sociological Association. Available at https://osf.io/preprints/socarxiv/tf76d/.

Schnabel, Landon. 2016. “The Gender Pray Gap: Wage Labor and the Religiosity of HighEarning Women and Men.” Gender \& Society 30(4):643-69.

Schnabel, Landon. 2017a. “Gendered Religiosity.” Review of Religious Research. Online 1st. Schnabel, Landon. 2017b. Opiate of the Masses? Social Inequality, Religion, and Politics. Paper presented at the annual meetings of the American Sociological Association. Available at https://osf.io/preprints/socarxiv/dnz2w/.

Smilde, David and Matthew May. 2015. "Causality, Normativity, and Diversity in 40 Years of U.S. Sociology of Religion: Contributions to Paradigmatic Reflection.” Sociology of Religion: A Quarterly Review 76(4):369-88.

Smith, Christian et al. 2013. "Roundtable on the Sociology of Religion: Twenty-Three Theses on the Status of Religion in American Sociology-A Mellon Working-Group Reflection.” Journal of the American Academy of Religion 81(4):903-38.

Stark, Rodney. 2002. "Physiology and Faith: Addressing the 'Universal' Gender Difference in Religious Commitment.” Journal for the Scientific Study of Religion 41(3):495-507.

Sullins, D.Paul. 2006. “Gender and Religion: Deconstructing Universality, Constructing Complexity.” American Journal of Sociology 112(3):838-80.

Thompson, Edward H. 1991. "Beneath the Status Characteristic: Gender Variations in Religiousness.” Journal for the Scientific Study of Religion 30(4):381-94.

Thompson, Edward H. and Kathryn R. Remmes. 2002. "Does Masculinity Thwart Being Religious? An Examination of Older Men’s Religiousness.” Journal for the Scientific Study of Religion 41(3):521-32. 
Whitehead, Andrew. 2013. “Gendered Organizations and Inequality Regimes.” Journal for the Scientific Study of Religion 52(3):476-93.

Wilde, Melissa and Lindsay Glassman. 2016. “How Complex Religion Can Improve Our Understanding of American Politics.” Annual Review of Sociology 42(1):407-25.

Winter, Nicholas J. G. 2010. “Masculine Republicans and Feminine Democrats: Gender and Americans’ Explicit and Implicit Images of the Political Parties.” Political Behavior 32:587-618.

Woodhead, Linda. 2008. “Gendering Secularization Theory.” Social Compass 55(2):187-93.

Zion-Waldoks, Tanya. 2015. "Politics of Devoted Resistance: Agency, Feminism, and Religion among Orthodox Agunah Activists in Israel.” Gender \& Society 29(1):73-97. 


\section{FIGURES AND TABLES}

\section{Figure 1: Gender Gaps in Religiosity by Jewish Subgroups in Israel}

\section{In Israel, Jewish men's greater religiousness varies by identity category and religion measure}

$\%$ of people who attend religious services weekly, pray daily, and say religion is very important

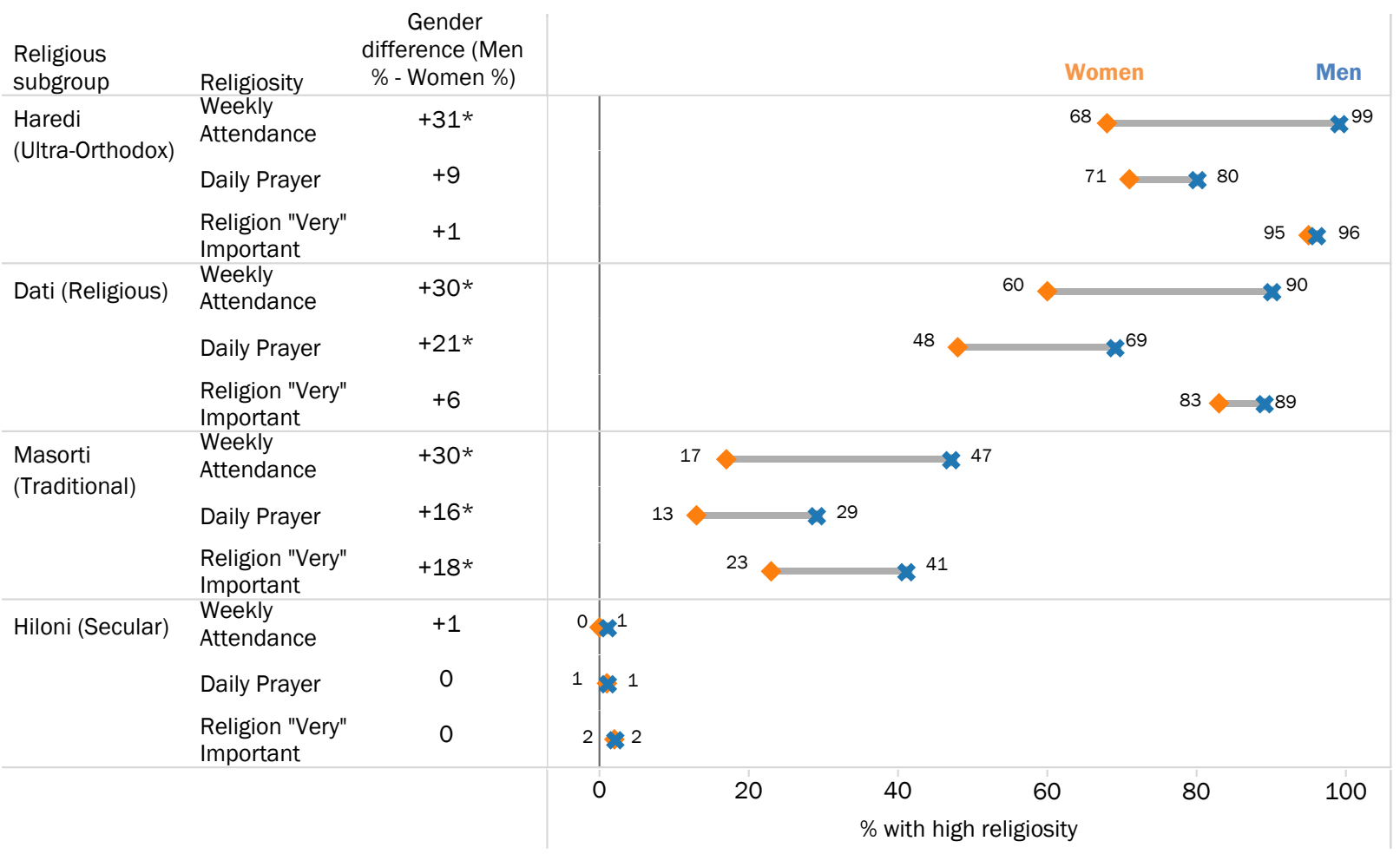


Table 1: Gender Gaps in Religiosity by Religious Subgroups in Israel

\section{Men appear more religious than women in Israel, but only among Jews}

$\%$ of people who attend religious services weekly, pray daily, and say religion is very important

\begin{tabular}{|c|c|c|c|}
\hline Israel Country Average & Men & Women & $\begin{array}{l}\text { Gender } \\
\text { difference } \\
\text { (Men \% - } \\
\text { Women \%) }\end{array}$ \\
\hline Weekly Attendance & $40 \%$ & $21 \%$ & +19 \\
\hline Daily Prayer & 30 & 24 & +6 \\
\hline Religion Very Important & 39 & 33 & +6 \\
\hline \multicolumn{4}{|l|}{ Jews } \\
\hline Weekly Attendance & 37 & 18 & +19 \\
\hline Daily Prayer & 26 & 16 & +11 \\
\hline Religion Very Important & 35 & 25 & +9 \\
\hline \multicolumn{4}{|l|}{ Muslims } \\
\hline Weekly Attendance & 61 & 36 & +25 \\
\hline Daily Prayer & 53 & 69 & -16 \\
\hline Religion Very Important & 61 & 76 & -15 \\
\hline \multicolumn{4}{|l|}{ Christians } \\
\hline Weekly Attendance & 35 & 40 & -5 \\
\hline Daily Prayer & 31 & 37 & -7 \\
\hline Religion Very Important & 51 & 63 & -12 \\
\hline \multicolumn{4}{|l|}{ Druze } \\
\hline Weekly Attendance & 17 & 32 & -15 \\
\hline Daily Prayer & 20 & 32 & -12 \\
\hline Religion Very Important & 44 & 55 & -11 \\
\hline \multicolumn{4}{|c|}{$\begin{array}{l}\text { Source: Pew Israel Survey, } 2014(\mathrm{~N}=5,601) \\
\text { Note: Weighted percentages. Differences calculated based on } \\
\text { unrounded numbers. Bolded numbers indicate gender difference } \\
\text { significant at } p<.05\end{array}$} \\
\hline
\end{tabular}


Table 2: ALSOS Regression of Gender Gaps and How They Vary Across Religious Groups

\begin{tabular}{|c|c|c|c|c|c|c|}
\hline \multirow[b]{2}{*}{ Measures } & \multicolumn{2}{|c|}{ Attendance Frequency } & \multicolumn{2}{|c|}{ Prayer Frequency } & \multicolumn{2}{|c|}{ Importance of Religion } \\
\hline & $\begin{array}{l}\text { Without } \\
\text { Controls }\end{array}$ & $\begin{array}{c}\text { With } \\
\text { Controls }\end{array}$ & $\begin{array}{l}\text { Without } \\
\text { Controls }\end{array}$ & $\begin{array}{c}\text { With } \\
\text { Controls }\end{array}$ & $\begin{array}{l}\text { Without } \\
\text { Controls }\end{array}$ & $\begin{array}{c}\text { With } \\
\text { Controls }\end{array}$ \\
\hline \multicolumn{7}{|c|}{ Gender Main Effects (These gender main effects coefficients can be interpreted as Jewish women vs. Jewish men) } \\
\hline Female & $\begin{array}{l}-0.93 \\
(0.07)\end{array}$ & $\begin{array}{l}-0.93 \\
(0.06)\end{array}$ & $\begin{array}{l}-0.64 \\
(0.08)\end{array}$ & $\begin{array}{l}-0.68 \\
(0.08)\end{array}$ & $\begin{array}{l}-0.13 \\
(0.04)\end{array}$ & $\begin{array}{l}-0.13 \\
(0.04)\end{array}$ \\
\hline \multicolumn{7}{|c|}{ Religion Main Effects (Jewish Reference) } \\
\hline Muslim & $\begin{array}{c}0.66 \\
(0.14)\end{array}$ & $\begin{array}{c}0.43 \\
(0.15)\end{array}$ & $\begin{array}{c}2.02 \\
(0.17)\end{array}$ & $\begin{array}{c}1.79 \\
(0.18)\end{array}$ & $\begin{array}{c}0.81 \\
(0.05)\end{array}$ & $\begin{array}{c}0.60 \\
(0.06)\end{array}$ \\
\hline Christian & $\begin{array}{l}-0.48 \\
(0.17)\end{array}$ & $\begin{array}{l}-0.61 \\
(0.17)\end{array}$ & $\begin{array}{c}0.72 \\
(0.17)\end{array}$ & $\begin{array}{c}0.54 \\
(0.18)\end{array}$ & $\begin{array}{c}0.62 \\
(0.08)\end{array}$ & $\begin{array}{c}0.49 \\
(0.09)\end{array}$ \\
\hline Druze & $\begin{array}{l}-0.73 \\
(0.16)\end{array}$ & $\begin{array}{l}-0.84 \\
(0.16)\end{array}$ & $\begin{array}{l}-0.24 \\
(0.21)\end{array}$ & $\begin{array}{l}-0.41 \\
(0.20)\end{array}$ & $\begin{array}{c}0.54 \\
(0.08)\end{array}$ & $\begin{array}{c}0.39 \\
(0.08)\end{array}$ \\
\hline \multicolumn{7}{|c|}{ Interactions between Female and Religion (Male and Jewish Reference) } \\
\hline Female*Muslim & $\begin{array}{c}0.07 \\
(0.18)\end{array}$ & $\begin{array}{l}-0.06 \\
(0.19)\end{array}$ & $\begin{array}{c}1.45 \\
(0.23)\end{array}$ & $\begin{array}{c}1.31 \\
(0.24)\end{array}$ & $\begin{array}{c}0.31 \\
(0.07)\end{array}$ & $\begin{array}{c}0.27 \\
(0.08)\end{array}$ \\
\hline Female*Christian & $\begin{array}{c}1.27 \\
(0.24)\end{array}$ & $\begin{array}{c}1.15 \\
(0.24)\end{array}$ & $\begin{array}{c}1.14 \\
(0.26)\end{array}$ & $\begin{array}{c}0.99 \\
(0.27)\end{array}$ & $\begin{array}{c}0.34 \\
(0.11)\end{array}$ & $\begin{array}{c}0.24 \\
(0.11)\end{array}$ \\
\hline Female*Druze & $\begin{array}{c}1.41 \\
(0.26)\end{array}$ & $\begin{array}{c}1.25 \\
(0.26)\end{array}$ & $\begin{array}{c}1.07 \\
(0.29)\end{array}$ & $\begin{array}{c}0.85 \\
(0.29)\end{array}$ & $\begin{array}{c}0.32 \\
(0.11)\end{array}$ & $\begin{array}{c}0.18 \\
(0.11)\end{array}$ \\
\hline Constant & 3.50 & 4.48 & 3.09 & 3.83 & 2.75 & 3.73 \\
\hline$N$ & 5,547 & 5,547 & 5,529 & 5,529 & 5,540 & 5,540 \\
\hline$R^{2}$ & 0.08 & 0.15 & 0.19 & 0.23 & 0.12 & 0.19 \\
\hline
\end{tabular}

Standard errors in parentheses

Source: Pew Israel Survey 2014

Note: People who did not list any of the four main religious groups were excluded from these analyses and sample sizes vary based on how many cases had complete and detailed information on the relevant outcome measure. Alternating least squares optimized scaling (ALSOS) regression used for all outcomes.

Control models include age, marital status, parental status, years of education, subjective economic standing, and employment status.

Bolded coefficients indicate significance at $p<.05$ 
Table 3: Gender Gaps among Jews in Israel on 25 Additional Measures

\section{Although women and men do not differ on all measures, men tend to be score higher when they differ}

$\%$ of people with the stated response

\section{Belonging (i.e., Jewish Identity)}

Not at all comfortable with child marrying a secular Jewa

Yeshiva/kolel is highest education respondent has received

Following Jewish law (halakha) essential to being Jewish

Being Jewish is mainly a matter of religion

Describe self as Jewish over Israeli

Very important for your children to get a Jewish education

Being Jewish is very important

Proud to be Jewish

\section{Behaving (i.e., Religious Practice)}

Study text daily

Ride in no vehicles on Sabbath

Strictly observe all the Jewish religious tradition

Fasted all day during last Yom Kippur

Handle no money on Sabbath

Keep kosher outside home

Someone in home always lights Sabbath candles

Someone in home always lights Hanukkah candles

Keep kosher in home

Participated in traditional Seder last Passover

Never eat pork

Wear religious head covering

\section{Believing (i.e., Religious Certainty)}

Strongly oppose women praying at the Kotel (Western Wall)

Absolutely certain God exists

Do not believe in evolution

God gave Israel to Jews (limited to people who believe in God)

Belief in God or universal spirit

$\begin{array}{ccc}\begin{array}{c}\text { Jewish } \\ \text { Men }\end{array} & \begin{array}{c}\text { Jewish } \\ \text { Women }\end{array} & \begin{array}{c}\text { Gender difference } \\ \text { (Men \% - Women \%) }\end{array} \\ 37 \% & 27 \% & +10 \\ 10 & 2 & +8 \\ 38 & 32 & +7 \\ 25 & 19 & +6 \\ 58 & 56 & +2 \\ 47 & 45 & +2 \\ 55 & 54 & +1 \\ 96 & 96 & 0\end{array}$

$\begin{array}{lcr}15 & 4 & +11 \\ 39 & 33 & +7 \\ 25 & 17 & +7 \\ 64 & 57 & +6 \\ 46 & 40 & +5 \\ 54 & 50 & +4 \\ 45 & 42 & +3 \\ 53 & 51 & +3 \\ 64 & 62 & +2 \\ 68 & 67 & +1 \\ 83 & 84 & -1 \\ 35 & -- \text { b } & --b\end{array}$

$\begin{array}{llr}29 & 19 & +10^{\circ} \\ 54 & 49 & +5 \\ 48 & 43 & +5 \\ 85 & 83 & +2 \\ 78 & 80 & -1\end{array}$

Source: Pew Israel Survey, $2014(\mathrm{~N}=3,789)$

Note: Weighted percentages. Bolded numbers indicate gender difference significant at $p<.05$

a Was not asked of secular Jews

${ }^{\mathrm{b}}$ Head covering was only asked of men, a survey choice that illustrates of the gendered nature of some religious obligations and expectations that vary from religion to religion.

"Although not strictly a measure of religious belief, we included this measure as an example of "gendered" ways of expressing religion. 